\title{
Separate coronary arteries originating from the right sinus of Valsalva
}

Niezależne odejście tętnic wieńcowych od prawej zatoki Valsalvy

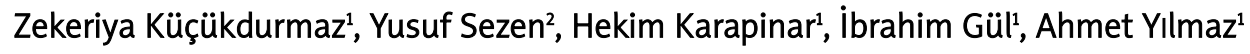 \\ ${ }^{1}$ Cardiology Department, Cumhuriyet University Medical School, Sivas, Turkey \\ ${ }^{2}$ Cardiology Department, Harran University Medical School, Sanliurfa, Turkey
}

Post Kardiol Interw 2012; 8, 1 (27): 48-50

DOI: $10.5114 /$ pwki.2012.27925

\begin{abstract}
Three separate coronary arteries originating from the right or left coronary sinus of Valsalva are exceedingly rarely seen coronary anomalies. The clinical course depends on the site of origin and the anatomical trace. We report a case with all coronary arteries arising from the right sinus of Valsalva with different ostia.
\end{abstract}

Key words: coronary anomaly, origin, right sinus of Valsalva

\section{Streszczenie}

Odrębne odejście trzech tętnic wieńcowych od prawej lub lewej zatoki Valsalvy jest niezwykle rzadką anomalią. Przebieg kliniczny zależy od miejsca odejścia i przebiegu anatomicznego tętnic. Przedstawiamy przypadek, w którym wszystkie tętnice wieńcowe odchodziły niezależnie od prawej zatoki Valsalvy.

Słowa kluczowe: anomalia wieńcowa, ujście, prawa zatoka Valsalvy

\section{Introduction}

Coronary artery anomalies are seen very rarely. They were found in only $1-1.3 \%$ of coronary arteriograms and 0.3-0.78\% of performed autopsies [1-4]. In addition, three separate coronary arteries originating from the right or left coronary sinus of Valsalva are exceedingly rarely seen coronary anomalies. The clinical course depends on the site of origin and the anatomical trace. We report a case with entire coronary arteries arising from the right sinus of Valsalva with different ostia.

\section{Case report}

A 55-year-old man was admitted to the outpatient clinic with stable angina pectoris for four years. The past medical history was unremarkable. His blood pressure was $140 / 90 \mathrm{~mm} \mathrm{Hg}$ and his fasting blood glucose was 234 $\mathrm{mg} / \mathrm{dl}$. The electrocardiography showed normal findings. The treadmill exercise was positive, so we performed coro- nary angiography. We observed all coronary arteries arising from the right sinus of Valsalva with different ostia. The three separate ostia for each coronary artery were confirmed by injection of contrast material into the right sinus of Valsalva (Figures 1-3). The aortogram did not demonstrate any arteries arising from the left sinus of Valsalva. All coronary arteries were clear of plaques.

\section{Discussion}

Coronary artery anomalies were found in $1-1.3 \%$ of patients undergoing coronary arteriography [4]. These anomalies include anomalies of origin and distribution $(87 \%)$ and coronary artery fistulae (13\%) [4]. Coronary anomalies are usually discovered as incidental findings at the coronary angiography [4]. Eighty-one percent of anomalies are benign in character including separate origin of the left anterior descending (LAD) and circumflex (CX) arteries from the left sinus of Valsalva, ectopic origin of 


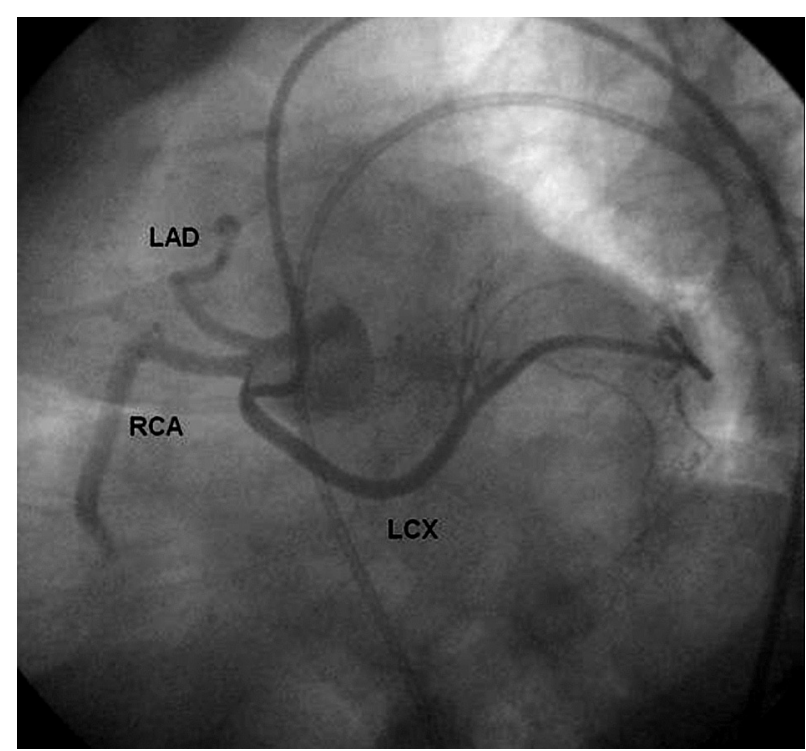

Fig. 1. LAD originating from right sinus of Valsalva, probably showing an interarterial course

Ryc. 1. Gałąź przednia zstępująca odchodząca od prawej zatoki Valsalvy, prawdopodobnie o przebiegu wewnątrztętniczym

the $\mathrm{CX}$ from the right sinus of Valsalva, ectopic coronary origin from the non-coronary sinus of Valsalva, anomalous coronary origin from the ascending aorta, absent CX, intercoronary communications, and small coronary artery fistulae [4]. Ninety percent of the anomalies are regarded as serious because of the association with angina pectoris, myocardial infarction (MI), syncope, cardiac arrhythmias, congestive heart failure, or sudden death [4-8], which include ectopic coronary origin from the pulmonary artery, ectopic coronary origin from the opposite aortic sinus, single coronary artery and large coronary fistulae.

The clinical course depends on the site of origin and the anatomical trace. Coronary anomalies whose trace is among the aortic and the pulmonary trunk are especially associated with increased mortality and morbidity, depending on the myocardial area at risk [2]. The dynamic compression during systole may compromise the coronary blood flow [2]. So we should be very cautious with an anomalous origin of the left coronary artery until we exclude the interarterial course between the aortic root and pulmonary trunk. This may be easily done with the use of computed tomography angiography, which has emerged as the preferred method for depicting the exact course of coronary anomalies. It seems to be especially important in the context of a positive exercise treadmill test, since we cannot exclude a "malignant" course of the LAD based on conventional angiography [9]. Also Opolski et al. showed that all patients with right-sided origin of the left main and left-sided origin of the right coronary artery showed an interarterial course and 3 were judged as 'malignant' because of the significant compression

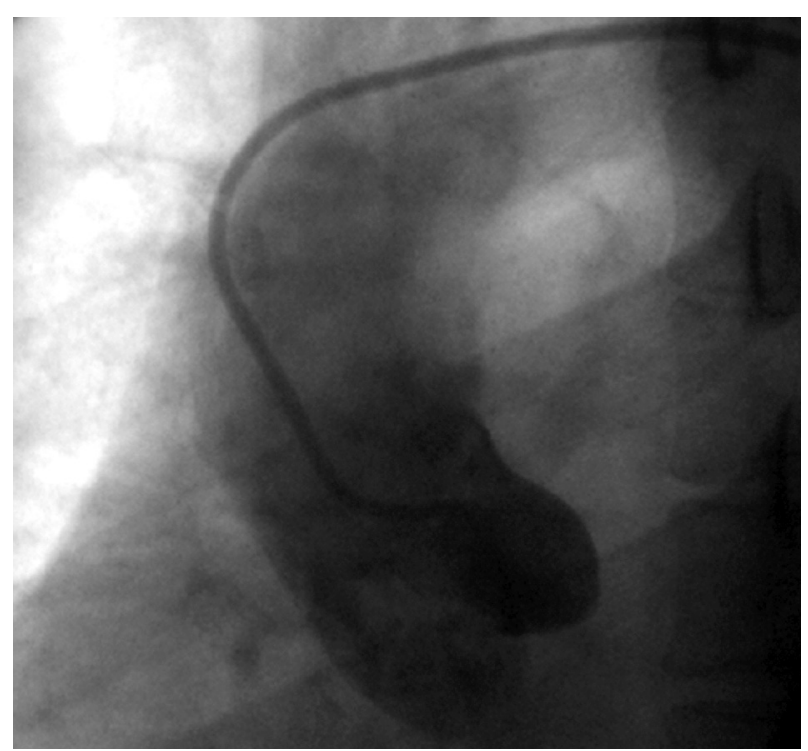

Fig. 2. No coronary artery originating from left sinus of Valsalva

Ryc. 2. Brak tętnic wieńcowych odchodzących od lewej zatoki Valsalvy

between the aortic root and the pulmonary trunk [9], which supports further investigation for patients with coronaries originating from another coronary sinus with positive treadmill exercise test. Besides abnormal coronary ostium, specifically a narrowed, slit-like coronary orifice,

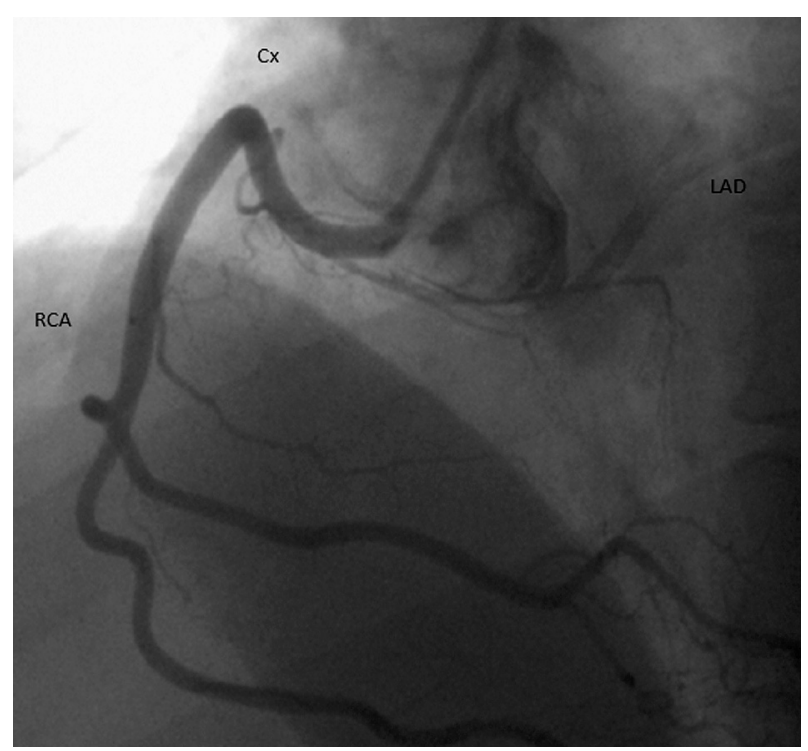

Fig. 3. Left anterior oblique view of right coronary system. LAD, CX and RCA, all originating from separate ostia from right coronary sinus

Ryc. 3. Obrazowanie prawej tętnicy wieńcowej w projekcji lewej przedniej skośnej. Niezależnie od prawej zatoki wieńcowej odchodzą GPZ, GO i PTW 
and the initial coronary artery course including an acute angle take-off with an aortic intramural course, may cause arrhythmia, MI and sudden cardiac death [10].

To the best of our knowledge, three separate coronary arteries originating from the right coronary sinus of Valsalva are seen exceedingly rarely, and we only found 38 cases with this anomaly in the literature.

\section{References}

1. Patel KB, Gupta H, Nath H, et al. Origin of all three major coronary arteries from the right sinus of Valsalva: clinical, angiographic, and magnetic resonance imaging findings and incidence in a select referral population. Catheter Cardiovasc Interv 2007; 69: 711-718.

2. Larsen Al, Ørn S, Barvik S, Nilsen DW. Anomalies of the coronary arteries originating from the right sinus of Valsalva. (1) Single coronary artery originating from the right sinus associated with fusion of the left and the non coronary cusp and atrophy of the left coronary ostium (2) Three separate coronary arteries originating from the right sinus of Valsalva. Int J Cardiol 2007; 115: e86-e89.

3. Zhang F, Ge JB, Qian JY, et al. Frequency of the anomalous coronary origin in the Chinese population with coronary artery stenosis. Zhonghua Nei Ke Za Zhi 2005; 44: 347-349.

4. Yamanaka O, Hobbs RE. Coronary artery anomalies in 126,595 patients undergoing coronary arteriography. Cathet Cardiovasc Diagn 1990; 21: 28-40.

5. Pigozzi F, Rizzo M. Sudden death in competitive athletes. Clin Sports Med 2008; 27: 153-181.

6. Cittadini F, Oliva A, Arena V, et al. Sudden cardiac death associated with a coronary artery anomaly considered benign. Int I Cardiol 2009; 133: e39-e40.

7. Araki H, Kageyama M, Inami S, et al. Right coronary artery to left ventricle fistula associated with three-vessel coronary artery disease: a case report. J Cardiol 2007; 50: 193-197.

8. Ng B, Maginot KR. Sudden cardiac death in young athletes: trying to find the needle in the haystack. WMJ 2007; 106: 335-342.

9. Opolski MP, Pregowski J, Kepka C, et al. Dual source computed tomography in visualization of coronary artery anomalies. Post Kardiol Interw 2008; 4: 133-145.

10. Taylor AJ, Byers JP, Cheitlin MD, Virmani R. Anomalous right or left coronary artery from the contralateral coronary sinus: "high-risk" abnormalities in the initial coronary artery course and heterogeneous clinical outcomes. Am Heart J 1997; 133: 428-435. 